\title{
Organizing specialized production: gender in the medieval Flemish wool cloth industry (c. 1250-1384)
}

\author{
SHENNAN HUTTON \\ University of California, Davis, One Shields Ave., Davis, CA 95616, USA
}

\begin{abstract}
In the earliest centuries of the Flemish wool cloth industry, the lowerlevel, preparatory stage of wool processing and spinning was organized by a form of 'putting-out' significantly different from later forms in the industry. It took place in and around the cities or smaller drapery centres rather than in rural areas, and women were prominent as middle-level organizers, managers and small entrepreneurs, despite their marginal status in or exclusion from the craft guilds. Using small bits of evidence from Flemish regulations and contracts from the earliest documented period of cloth production, this article analyses lowerlevel organization through the lens of gender. It shows that the production of yarn was organized by a broad middling level of drapers and small marketsellers, who were women, men and husbands and wives working together. The gendered lens distinguishes this middle level, which was indispensable to the efficient production of wool cloth in medieval Flanders.
\end{abstract}

In 1298, a woman identified as Marie, daughter of Jaquemon Routaert, submitted a petition to a Flemish comital commission investigating complaints against local bailiffs. ${ }^{1}$ Marie complained that the bailiff of Ghent had confiscated her sack of English wool while he was enforcing a county-wide ban on working English wool. Marie claimed that she should be compensated for the damage she sustained, 'for the wool then belonged to my mother', and was thus not newly imported. ${ }^{2}$ Although we have no record of the commission's decision, Marie Routaert's case offers a glimpse into the often invisible middle and lower levels of medieval Flemish wool cloth production. Valued at 28 sterling marks, the sack probably contained

${ }^{1}$ This article was based in part on research in the Stadsarchief Gent (Ghent City Archives). G. Espinas and H. Pirenne (eds.), Recueil de documents relatifs à l'histoire de l'industrie drapière en Flandre. Première partie: des origines à l'époque bourguignonne (Brussels, 1909; reissued by the Belgian Royal Commission for History, 1988) (EP), \#410, vol. II, 397-8.

2 'car le laine appartenoit à me mere adont, que Diex absoillie', EP, \#410, vol. II, 398. 
more wool than was required to make a single cloth. ${ }^{3}$ How was Marie's mother able to purchase such an expensive quantity of wool, apparently without the involvement of Marie's father? What was Marie doing with the sack when it was confiscated by the bailiff? Was she trying to sell it, either entirely, or in small lots? Was she transporting it to carders, combers or spinners? While I cannot answer these questions about Marie herself, her petition and many other terse records from thirteenth- and fourteenthcentury Flanders provide insight into the lower and middle levels of wool yarn and cloth production.

Flanders was one of the first and most important centres of cloth production and urbanization in medieval Europe. In its earliest centuries, making wool cloth was an urban industry that drew thousands of women and men from the countryside into Ghent, Bruges, Ypres, Lille and Douai, and dozens of smaller towns. Although considerable scholarship exists about the wool cloth industry (or the drapery) in medieval Flanders, there has been less attention to the organization of the lower, or preparatory, level of production, even though labour on this level consumed more than half of the hours needed to produce cloth. ${ }^{4}$ The modern historiographical focus on guilds, competition among Flemish production centres and trade in wool and finished luxury cloth mirrors the emphasis that medieval merchants and Flemish civic leaders placed on recording documents relating to the higher levels of drapery production and trade, meaning that sources are scarce. Some historians have shown that in the initial stages of production, merchants, drapers and guildsmen (usually male) put out wool to combers, carders and spinners (usually female), while others have uncovered compelling evidence that women

${ }^{3}$ The document says that these were sterling marks of England, not Flanders: '28 mars des esterlins d'Engletiere'. However, this amount (18 English pounds sterling) was enough to purchase almost three 364 pound sacks of English wool in 1296-1301. J.H. Munro, Statistical Tables on Medieval and Early-Modern Textiles, Table 14, p. 35, www.economics.utoronto.ca/ wwwfiles/archives/munro5/MedTextileStats.pdf. Marie Routaert and/or the bailiff may have exaggerated the value of her sack of wool, or perhaps the 28 marks were in Flemish sterlings, a money of account that was worth one third of the Flemish pound groot. In this case, the sack would have been worth 4.66 pounds groot, or 2.25 English pounds sterling, the equivalent of 123 pounds. For the conversion rates, see P. Spufford, Handbook of Medieval Exchange (London, 1986), 213.

4 Among many other general works, see J.A. Van Houtte and R. Van Uytven, 'Nijverheid en handel 1300-1500', in Algemene Geschiedenis der Nederlanden, vol. IV (Haarlem, 1980), 87$111 ;$ J.H. Munro, 'Urban regulations and monopolistic competition in the textile industries of the late-medieval Low Countries', in E. Aerts and J.H. Munro (eds.), Textiles of the Low Countries in European Economic History. Proceedings of the Tenth International Economic History Congress: Session B-15 (Leuven, 1990), 41-52; M. Boone and W. Prevenier (eds.), La Draperie ancienne des Pays-Bas: Débouchés et stratégies de survie (14e-16e siècles): Actes du colloque tenu à Gand le 28 avril 1992/Drapery Production in the Late Medieval Low Countries: Markets and Strategies for Survival (14th-16th Centuries): Proceedings of the Colloquium Ghent, April 28th 1992 (Leuven and Apeldoorn, 1993); W. Endrei, 'Manufacturing a piece of woollen cloth in medieval Flanders: how many work hours?', in Aerts and Munro (eds.), Textiles of the Low Countries, 14-23; G. De Poerck, La Draperie médiévale en Flandre et en Artois: Technique et terminologie, 3 vols. (Bruges, 1951); D. Cardon, La Draperie au Moyen Âge: Essor d'une grande industrie Européenne (Paris, 1999). 
were also important as drapers, dyers and marketsellers. ${ }^{5}$ This article examines small bits of evidence from guild and city regulations, property inventories and contracts through the lens of gender to show that the lower level production - combing, carding and spinning - was organized not by a hierarchical putting-out system in which male elite entrepreneurs provided materials to rural workers, but by a middle managerial level. I argue that between 1250 and 1384 not only was much of the combing and spinning actually done in the cities rather than in the countryside, but also the sources suggest that networks of women (and men) centred in the towns and extending into the surrounding countryside produced individual wool cloths in the production stages before finishing. These sources also shed light on the changing nature of women's work over the course of the Middle Ages. Between 1250 and 1384 in the Flemish cities, women were not confined entirely to low-status and low-paid occupations (even though most were poor spinners, combers and carders) or to labour within a male-dominated household, the usual status relegated to them in studies of medieval women's work. ${ }^{6}$ While men dominated the highest level of status and profit in the industry, some women had access to middle-level managerial occupations as drapers and small marketsellers. Gender analysis actually distinguishes this middle level - women, men and married couples working together - who were indispensable to the efficient production of wool cloth in medieval Flanders.

The sources for this study are documents from the Ghent aldermen's registers and guild regulations and civic ordinances (known as keures) from a number of Flemish towns and production centres. ${ }^{7}$ Written by guild leaders and city officials, the keures reflect the point of view of those clustered in the higher and more profitable occupations of the industry. Officials did not consider non-guild, low-level occupations important enough to merit a great deal of attention. For example, a Bruges keure has 1 provision about wool preparation and 1 about spinning, in contrast to 12 about weaving and 5 about fulling. ${ }^{8}$ The officials' view privileged the later stages of cloth-making (weaving, stretching, fulling, shearing and finishing) even though these processes involved fewer labour hours.

The primary concern of the keures was quality control. Preserving the city's reputation depended on producing cloth with uniform

${ }^{5}$ M.C. Howell, Women, Production, and Patriarchy in Late Medieval Cities (Chicago, 1986); P. Stabel, 'Women at the market. Gender and retail in the towns of late medieval Flanders', in W. Blockmans, M. Boone and T. De Hemptinne (eds.), Secretum Scriptorum: Liber alumnorum Walter Prevenier (Leuven and Apeldoorn, 1999), 259-76; E.E. Kittell and K. Queller, "'Whether man or woman": gender inclusivity in the town ordinances of medieval Douai', Journal of Medieval and Early Modern Studies, 30 (2000), 63-100.

6 J.M. Bennett, Ale, Beer and Brewsters in England: Women's Work in a Changing World, 13001600 (New York and Oxford, 1996), 37-41; B.A. Hanawalt, 'Introduction', in B.A. Hanawalt (ed.), Women and Work in Preindustrial Europe (Bloomington, 1986), ix-x, among others.

7 EP; Annual Registers of the Aldermen of the Keure, City Archive of Ghent (Stadsarchief Gent (hereafter SAG)), series 301, no. 1 .

8 EP, \#138, vol. II, 362-8. 
characteristics and minimal defects. Officials appointed by the masters of the leading guilds, merchants and/or the city aldermen inspected cloth at various stages in the manufacturing process. ${ }^{9}$ In the keures, especially those written in French, clerks often gendered occupations - for men only, women only, or men and women, in the words of Ellen Kittell and Kurt Queller, 'gender dyads' ${ }^{10}$ Clerks might use the masculine term for inspectors, eswardeurs, the feminine term for spinners, fileresses, and a gender dyad, drapiers ne drapiere, for drapers. ${ }^{11}$ Although some keures used masculine forms alone, consistent use of gender dyads is a strong indication that both men and women practised an occupation.

\section{Factors influencing the organization of lower-level wool cloth production}

Although the earliest evidence of wool cloth production in Flanders dates from the eleventh century, there are no keures and few sources earlier than 1250. Many assumptions about the middle and lower levels of medieval Flemish cloth production are actually based on information from a relatively late period, the fifteenth and sixteenth centuries, because keures grew longer and more detailed in that period. This is problematic because Martha Howell and Ellen Kittell have shown that there were important changes in gender norms in property and law over these centuries. ${ }^{12} \mathrm{I}$ have argued elsewhere that similar changes in gender norms for work and credit occurred in Ghent during this period. ${ }^{13}$ To avoid distorting the pattern of earlier organization, this article only considers regulations from the thirteenth and fourteenth centuries, before 1384, the advent of the Burgundian dynasty (1384-1482). Although this political terminus does not mark abrupt changes in the industry, changes that disadvantaged women producers clearly increased and the industry shifted dramatically in the early fifteenth century. ${ }^{14}$ Georges Espinas and Henri Pirenne recognized this by dividing their collection of sources on the drapery industry into two sets of volumes, one pre-1384 and one post- $1384 .{ }^{15}$

The organization of the higher level of Flemish wool production (weaving, fulling, shearing and other finishing occupations) is well

${ }^{9}$ P. Stabel, 'Guilds in late medieval Flanders: myth and reality of guild life in an exportoriented environment', Journal of Medieval History, 30 (2004), 187-212, at 206.

${ }^{10}$ Kittell and Queller, "“Whether man or woman"', 64, 98-100.

11 EP, Arras, \#73, vol. I, 188-9, dated 1343.

12 M.C. Howell, Marriage Exchange: Property, Social Place, and Gender in Cities of the Low Countries, 1300-1550 (Chicago, 1998); E.E. Kittell, 'Women, audience, and public acts in medieval Flanders', Journal of Women's History, 10 (1998), 74-96; Kittell and Queller, "'Whether man or woman"'.

${ }^{13}$ S. Hutton, Women and Economic Activities in Late Medieval Ghent (New York, 2011), 123-42.

14 Howell, Marriage Exchange; Hutton, Women, 127-42; E.E. Kittell, 'Guardianship over women in medieval Flanders: a reappraisal', Journal of Social History, 31 (1998), 896-930, at 909.

15 EP, vols. I-IV pre-1384, vols. V-VIII post-1384. 


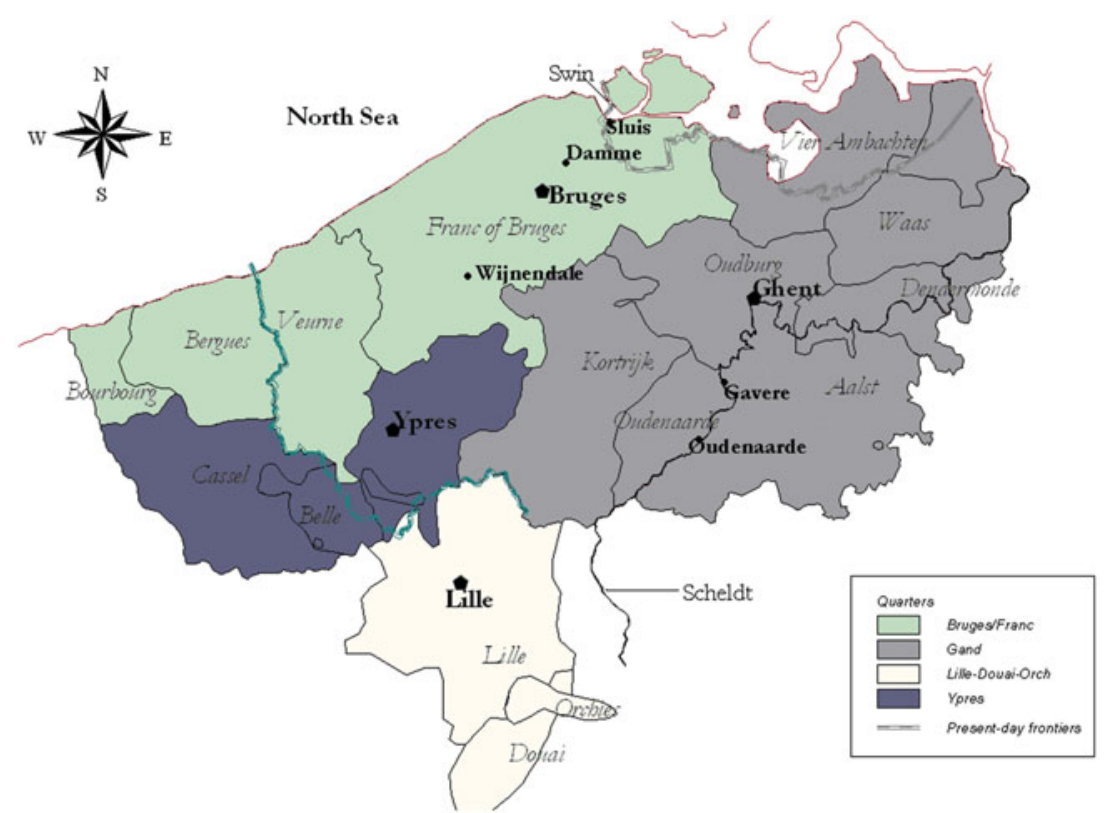

Figure 1: (Colour online) The medieval county of Flanders (C) Tim Soens. GISTorical Antwerp. Used with permission.

understood as small commodity production or proto-industrial development controlled by the cloth guilds and urban merchants in a corporatist structure. $^{16}$ The political power of the guilds and the institutional structures in the Flemish cities (see Figure 1) protected small-scale, independent production and limited the growth of polarization and proletarianization. ${ }^{17}$ The interests of guilds and merchants, institutional structures of guild and civic regulations, inheritance custom, credit, women's legal capability and economic gender roles supported a similar small-scale organization for the lower level of wool cloth production and hindered scale enlargement. ${ }^{18}$

The organization of the lower-level drapery depended on a number of factors. First, production was highly specialized and decentralized into numerous shops, houses and yards. There were many specialized occupations which were spatially decentralized in distinct locations, such as the fullery, the shearing (or picking) shop and the stretching frame

${ }^{16}$ Munro, 'Urban regulations'; M.C. Howell and R.S. DuPlessis, 'Reconsidering the early modern economy: the cases of Leiden and Lille', Past and Present, 94 (1982), 49-84; J.R. Farr, Artisans in Europe, 1300-1914 (Cambridge, 2000), 20-32.

17 B. Van Bavel, Manors and Markets: Economy and Society in the Low Countries, 500-1600 (Oxford, 2010), 391.

18 Ibid., 203. 
yards ('in ghereederien, in volrien, in wiederijen, an de ramen'), as a Ghent ordinance specified. ${ }^{19}$ Table 1 lists many of the occupations and the number of labour hours required for each, based on the studies of Guy De Poerck and Walter Endrei. ${ }^{20}$ Using the total of 1,033 labour hours that Endrei calculated were needed to produce a broadcloth of 35 square metres, I have estimated the number of workers needed for each task, loosely based on 40 hours per worker.

The second factor was the dominance of high-status merchants and elite guildsmen over production and the labour of low-status female occupations. Figure 2 shows the status of occupations, as a method of comparing occupations in the absence of statistics. The appointment of status is based on wages, profit share and the control that occupation had over conditions of production and/or other occupations. Circles and boxes show occupations that were gendered female or male respectively, while the combined symbol indicates an occupation that some keures identified by gender dyads. For certain occupations, there is a distinction between elite guild leaders with high status and ordinary guildsmen with middling status. The most significant distinction was that occupations before weaving were low status, not organized into guilds, not profitable and largely female, while the occupations after weaving were mainly middle status, organized into guilds, more profitable and largely male.

The control of high-status occupations over production shows in the restrictive regulations they prescribed for combers, carders and spinners. Some regulations emphasized quality control, prohibiting night work, singed wool or wool washed before it had been inspected. ${ }^{21}$ Other regulations show that low-level producers often did not own the wool they processed. In Bruges, a spinner (spinnicghe) could not have more than one person's wool (eens menschen wulle) in her house (in hare huus), on pain of losing her wages. ${ }^{22}$ Saint-Pol forbade a spinner from spinning her own work (oevre que siene soit) if she had another's work (autrui oevre). ${ }^{23}$ Not only were combers, carders and spinners usually prohibited from making cloth themselves, but keures placed limits on the amount of wool they could have in their houses at any one time. In Ypres, for example, no comber, spinner or carder was allowed to have more than 3 stones of wool in her house, or to possess a weighing scale. ${ }^{24}$ Since 3 stones (18 modern pounds) were enough to keep two spinners busy for a week, the prescription was intended to restrict the ability of these women to amass

19 EP, Ghent, 1357-58, \#457, no. 1, vol. II, 485.

20 De Poerck, Draperie; Endrei, 'Manufacturing'; Cardon, Draperie.

21 EP, Arras, late fourteenth century, \#77, nos. 11 and 12, vol. I, 196; Bruges, late thirteenth century, \#142, nos. 1, 2, 14 and 15, vol. I, 455-6; Saint-Omer, 1250-1325, \#651, no. 122, vol. III, 248; Aire, 1358-59, \#6, vol. I, 18-19; Tamise, 1362, \#709, nos. 5-7, vol. III, 345; Ypres, end of thirteenth century, \#738, vol. III, 474-6.

22 EP, Bruges, late thirteenth century, \#142, no. 11, vol. I, 456.

23 EP, Saint-Pol, 1383, \#706, no. 4, vol. III, 336.

24 EP, Ypres, 1280, \#754, no. 31, vol. III, 461. 
Table 1: Occupations and hours in medieval Flemish wool cloth production

\begin{tabular}{|c|c|c|c|}
\hline $\begin{array}{l}\text { Occupation (in order of } \\
\text { production process) }\end{array}$ & $\begin{array}{l}\text { Male or } \\
\text { female }\end{array}$ & $\begin{array}{l}\text { Hours of } \\
\text { labour } \\
\text { required to } \\
\text { make } 35 \\
\text { sq.m. cloth }\end{array}$ & $\begin{array}{c}\text { Number of } \\
\text { workers } \\
\text { required } \\
\text { (based on } 40 \\
\text { hour week) }\end{array}$ \\
\hline \multicolumn{4}{|l|}{ Lower level } \\
\hline Woolbreaker & male & 50 & 1 \\
\hline Washer & $\begin{array}{c}\text { male and } \\
\text { female }\end{array}$ & & $?$ \\
\hline Sorter & female & & 1 \\
\hline $\begin{array}{l}\text { Shearer (estonderesses, } \\
\text { tonderesses) }\end{array}$ & female & & 1 \\
\hline Beater & male & & 1 \\
\hline Comber & female & 23 & 1 \\
\hline Carder & female & 46 & 1 \\
\hline Spinner & female & 503 & 12 \\
\hline Total preparation phase & & 622 & 18 \\
\hline \multicolumn{4}{|l|}{ Weaving phase } \\
\hline Reeler & $\begin{array}{l}\text { male or } \\
\text { female }\end{array}$ & 5 & 1 \\
\hline Warp-winder & $\begin{array}{l}\text { male or } \\
\text { female }\end{array}$ & $45(40-50)^{\mathrm{b}}$ & 1 \\
\hline Weaver & male & 80 & 2 \\
\hline Total weaving phase & & 130 & 4 \\
\hline \multicolumn{4}{|l|}{ Finishing } \\
\hline Fuller & male & 150 & 3 \\
\hline Shearer & male & 40 & 1 \\
\hline Raiser/napper and picker & $\begin{array}{l}\text { male or } \\
\text { female }\end{array}$ & 80 & 2 \\
\hline Dyer & $\begin{array}{l}\text { male or } \\
\text { female }\end{array}$ & 4 & 3 \\
\hline $\begin{array}{l}\text { Tenterer, presser and other } \\
\text { finishers }\end{array}$ & male & 8 & $?^{\mathrm{c}}$ \\
\hline Total finishing phase & & 281 & $14-18$ \\
\hline Total & & 1,033 & $34-8$ \\
\hline
\end{tabular}

'The chart uses Endrei's figures, 'Manufacturing', 14-20.

${ }^{b}$ Endrei includes spooling and warp-winding in his weaving stage. He calculated 80 hours for weaving (which had to be done by two weavers simultaneously, together working for 40 hours) and 40-50 hours for warp-winding, but made no individual calculation for reeling. The figures of 6 and 44 hours are my own rough calculations.

${ }^{c}$ Endrei points out that the finishing stage took a lot of time but not that many working hours. Also, multiple workers were needed for short periods of time because the wet cloth was heavy and bulky, 'Manufacturing', 20. 


\section{HIGH LEVEL}

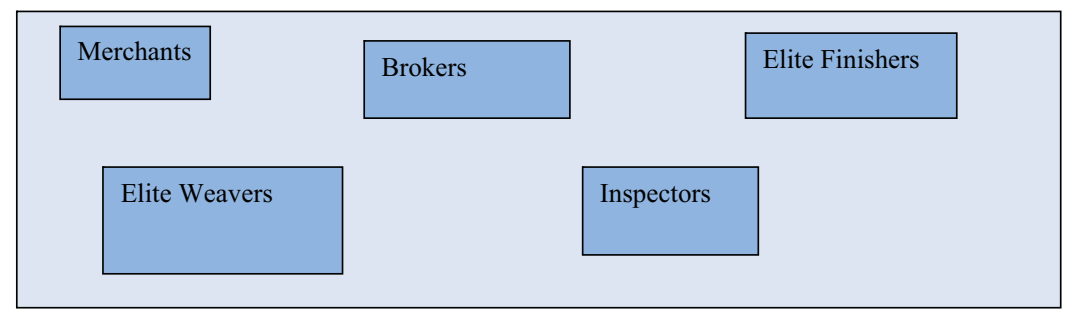

MIDDLING LEVEL

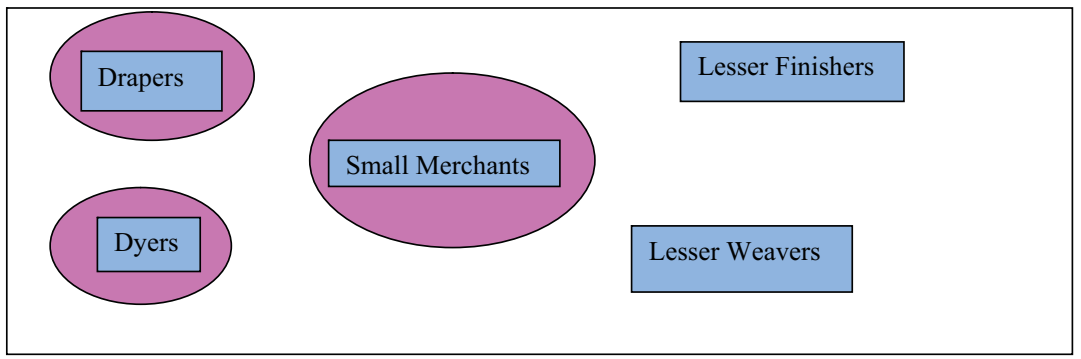

\section{LOW LEVEL}

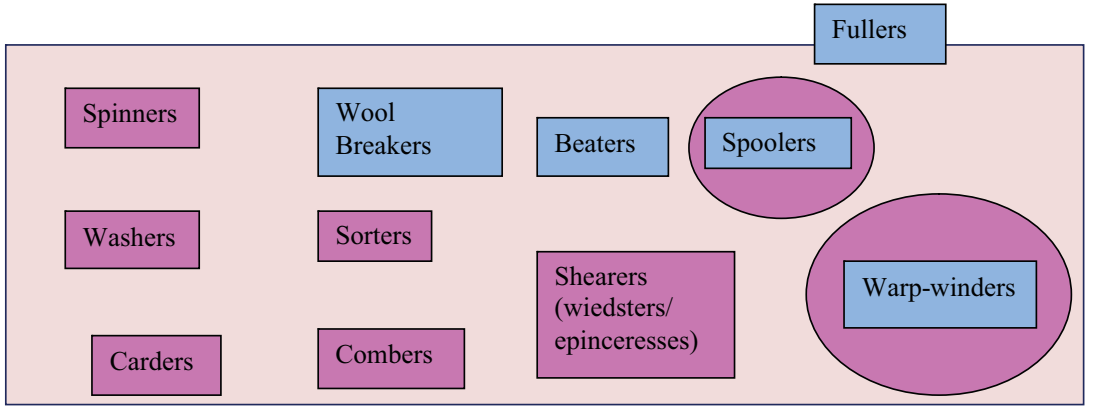

Figure 2: (Colour online) Status of occupations in the medieval Flemish wool cloth industry

larger quantities of wool, which they might sell or distribute to others, after weighing it themselves on their own scales. A late thirteenth-century Arras ordinance authorized inspectors from the Wool Office to go into spinners' houses if they suspected fraudulent practices. ${ }^{25}$ The Audenarde keure forbade carders and combers from evading home inspections by officials by hiding the wool or taking it over to a neighbour's house. ${ }^{26}$ It is

${ }^{25} \mathrm{EP}$, Arras, late thirteenth century, \#77, no. 14, vol. I, 196.

${ }^{26}$ EP, Audenarde, 1338, \#118, no. 7, vol. I, 266. 
not difficult to imagine combers, carders and spinners chafing under these invasive and paternalistic regulations, even though the sheer number of inspectors required to enforce these regulations on a regular basis seems beyond the capacity of any medieval city. It is also note-worthy that the keures envision these workers as living in or possibly nearby the city or smaller drapery centre. In any case, these low-level producers were clearly subordinate, and the gendering of an occupation as predominantly female usually meant that it held low status.

In contrast, weavers, always envisioned as male (teliers, wevers), were organized into guilds in most cities, and these often held substantial political power. ${ }^{27}$ Guild members were not equal economically, since there were elite weavers who imported wool from and exported finished cloth to international merchants, while other weavers were dependent on the elite weavers for supplies and credit or worked for them as subcontractors. ${ }^{28}$ However, the political and economic power of the weavers guild meant that even its poorest members had middling status, and in the eyes of contemporaries were far more important than any of the low-level workers who had handled the yarn before weaving. Other guild occupations, such as dyeing and fulling, held middle status. Finishers were almost always identified as men only and held high status, as they often invested in exporting cloth. ${ }^{29}$ While the specific elite occupations or groups that controlled cloth production differed from city to city, they all insured their dominance by participating in the city government, holding the principal guild offices, importing wool or dyestuffs and exporting finished cloth in bulk. Ordinary guild members often did not own the cloth they processed and did not share in the status or profits of these leaders.

Nevertheless, all guild-organized, male-dominated occupations enjoyed higher status than any low-level occupation. Consider the contrast of the above with the one finishing occupation performed by women. This worker was the picker (esbouresse, espinceresse, esbuqueresse,

27 EP, Ypres, end of thirteenth century, \#753, nos. 6 and 36, vol. III, 459 and 462.

${ }^{28} \mathrm{H}$. Van Werveke, De koopman-ondernemer en de ondernemer in de Vlaamsche lakennijverheid van de middeleeuwen (Antwerp, 1946), 22; M. Boone, 'L'Industrie textile à Gand au bas Moyen Âge ou les resurrections successives d'une activité réputée moribonde', in Boone and Prevenier (eds.), La Draperie ancienne des Pays-Bas; C. Lis and H. Soly, 'Corporatisme, onderaanneming en deregulering van de arbeidsmarkt', Tijdschrift voor Sociale Geschiedenis, 20 (1994), 365-90; and C. Lis and H. Soly, Worthy Efforts: Attitudes to Work and Workers in Pre-industrial Europe (Leiden and Boston, 2012); Van Bavel, Manors, 203-4.

${ }^{29}$ There are a few exceptions. A complaint from Douai in 1250 indicates that wives of shearers/cloth merchants accompanied their husbands to the Champagne fairs, and both sheared and sold cloth at their husbands' booths. EP, \#225, vol. II, 34-6; a 1350 Ghent ordinance identified members of the finishers' guild with a gender dyad (wijf of man), \#444, vol. II, 474. A 1384 Lille ordinance used a gender dyad (lichieres ou liceresse) for stretching, \#608, no. 7, vol. III, 26. R. Holbach, 'Some remarks on the role of "puttingout" in Flemish and Northwest European cloth production', in Boone and Prevenier (eds.), La Draperie ancienne des Pays-Bas, 231-2; De Poerck, Draperie, vol. III: 102; M. Boone, Gent en de Bourgondische hertogen ca. 1384-ca. 1453. Een sociaal-politieke studie van een staatsvormingproces (Brussels, 1990), 60, 71. 
wiedeghe, wiedsterigge), who washed the cloth after shearing and removed the nap and lint. A 1377 ordinance from Arras classified the espinceresse among combers, carders, spinners and spoolers, all identified in the female form, as it restricted their ability to take on work. ${ }^{30}$ The 1338 Audenarde keure forbade wietsterigghen to start picking a second cloth before they had finished the first. ${ }^{31}$ Lack of guild organization for this and other predominantly female occupations was a major disadvantage for women producers. $^{32}$ Since guild leaders, aldermen and clerks who prescribed the keures were exclusively male, the power relationship between high-status and low-status occupations was heavily gendered.

However, there were massive numbers of women producers, as a result of the third factor influencing production, the labour-intensive bottleneck created by spinning, and to a lesser extent, combing. ${ }^{33}$ Before the fourteenth century, all wool was combed, a task performed by female workers (pineresses, cammighen, kemsterighen), and after, warp thread was still combed, while weft thread was carded. ${ }^{34}$ Combing for the warp and carding for the weft thread together took 69 hours, while spinning took 503 hours, making it by far the most labour-intensive occupation in the drapery. Through the thirteenth and most of the fourteenth centuries, the largely female spinners (filieres, fileuses, spinsters) spun yarn with a distaff and spindle, and even later, spinning wheels could only be used for weft thread. ${ }^{35}$ Using the 1356-58 Ghent militia record, which listed 5,130 weavers in this city with a total population of 64,000 , makes possible the rough calculation that there must have been 30,780 spinners in the city and nearby villages. ${ }^{36}$ While spinners had low status and earned low pay, there were more of them than any other occupation in the industry. Organizing and managing their production would have also involved many hours of labour.

The fourth factor influencing the organization of production is that lowlevel workers worked in their own living spaces, belonged to a variety of household types and lived in both the city and surrounding villages. Almost every keure mentions that combers, carders and spinners worked

${ }^{30}$ EP \#66, no. 15, vol. I, 170-1.

31 EP, Audenarde, 1338, \#118, no. 21, vol. I, 268.

32 Farr, Artisans, 35-6.

33 Endrei, 'Manufacturing', 17; Cardon, Draperie, 145-210.

34 J.H. Munro, 'Textile technology' and 'Textile workers', in J.R. Strayer (ed.), Dictionary of the Middle Ages (New York, 1982), 695; De Poerck, Draperie, 47-59.

35 De Poerck, Draperie, 62-4; Cardon, Draperie, 277-313; EP, Tamise, 1362, \#709, no. 5, vol. III, 345 .

36 To make one drap of 20 metres in length and 35 square metres in area required 12 spinners at 42 hours each to equal the same amount of labour by 2 weavers. Endrei quotes three estimates of the number of workers supported by one loom: 24 to 26 people (1593), 8 people and 14 people (1683.) Endrei, 'Manufacturing', 14. For a seventeenth-century Dutch comparison, see E. Van Nederveen Meerkerk, 'Market wage or discrimination? The renumeration of male and female spinners in the seventeenth-century Dutch Republic', Economic History Review, 63 (2010), 165-86, at 168-9. 
in their own houses. ${ }^{37}$ The woman producer was often not the owner of the house or the head of household, who might have been a male weaver, fuller or shearer whose wife, daughters and servants contributed to the household economy by spinning. However, to spin enough wool to keep the 5,130 Ghent weavers supplied, each of the 12,250 households in that city would have had to house two or three full-time spinners. Since it is also probable that many women worked only part time at spinning, the real number would have been even higher. Some spinners undoubtedly lived in outlying villages, but many also lived in the city. A late thirteenthcentury Arras ordinance authorized inspectors to go into spinners' houses if they suspected fraudulent practices, which would only be possible if those houses were in or nearby the town. ${ }^{38}$ Sometimes women lived together. In Audenarde, combers could only have two stones of wool, but if more combers were living together in one house, the regulation stated: 'they could have as many two stone [lots] of wool as there were combers living there'. ${ }^{39}$

Female cloth workers also lived and worked in female-headed households in the city, particularly the small houses of the court beguinages which were so prominent in Flemish cities in this period. ${ }^{40}$ A 1310 ordinance from Bergues-Saint-Winnoc exempted beguines from paying taxes on the cloth they produced, except for those beguines who were 'grandes drapierières' (large drapers). ${ }^{41}$ Whether they lived in the city or in nearby villages, the pattern of combers, carders and spinners working in their houses presented organizational and managerial challenges.

The final factor is that although wool was imported in large quantities, cloth was produced one cloth at a time. Wool was imported into the drapery centres in sacks, then broken down into smaller lots and resold to producers. ${ }^{42}$ Estimated at 364 pounds in weight, sacks of English wool cost between 5 and 6 pounds sterling in the fourteenth century, and comprised 85 per cent of the cloth production costs, compared to only 15 per cent for labour. ${ }^{43}$ Only elite merchants were able to purchase entire sacks of English wool in quantity, as the cost of one sack was roughly equivalent to six months' wages for a master artisan. ${ }^{44}$ However, each large drapery cloth,

37 EP, Arras, \#77, no. 14, vol. I, 196; Audenarde, 1338, \#118, no. 7, vol. I, 266; Bruges, late thirteenth century, \#142, no. 11, vol. I, 456.

38 EP, Arras, late thirteenth century, \#77, no. 14, vol. I, 196; see also Aire, 1358-59, \#8, no. 6, vol. I, 24.

39 EP, Audenarde, 1338, \#118, no. 6, vol. I, 265.

${ }^{40}$ W. Simons, Cities of Ladies: Beguine Communities in the Medieval Low Countries, 1200-1560 (Philadelphia, 2001).

41 EP, Bergues-Saint-Winnoc, 1310, \#125, vol. I, 307-8, see also Alost, 1321, \#17, vol. I, 42-3.

42 J. Munro, 'Symbiosis of towns and textiles: urban institutions and the changing fortunes of cloth manufacturing in the Low Countries and England, 1270-1570', Journal of Early Modern History, 3 (1999), 1-74, at 37-41, 53.

43 Munro, Statistical Tables, Table 14, p. 35; idem, 'Symbiosis', 53.

44 To support a family of four, a master artisan required 7 pounds in Flemish groten, or groats. D. Nicholas, Metamorphosis of a Medieval City: Ghent in the Age of the Arteveldes, 1302-1390 
approximately 5 feet in width and 60 feet in length, was made individually. For example, a regulation from Ypres instructed a draper to bring the cloth to the inspectors, who, upon approval, affixed a seal. Then, 'the draper should deliver the whole seal to the fuller, the fuller to the stretcher, and the stretcher to the shearer, and the shearer to the inspector' ${ }^{45}$ The flow of cloth from one producer to another, even for just this small portion of the manufacturing process, involved movement of the cloth (and the seal attached to it) to and from five locations. The sheer number of workers involved in lower-level production - 13 full-time and 6 part-time workers - suggests that it was an even more complex process. The tracking of thousands of individual cloths at different stages of manufacture could present a logistical nightmare.

Organization of the lower levels of the early Flemish wool cloth industry has usually been identified as 'putting out', which Rudolf Holbach defines as a system of decentralized production by independent artisans who have no connection with consumers and are dependent on an entrepreneur who provides raw materials and/or tools required for production, or provides the credit necessary to purchase those items, and then sells the finished product. ${ }^{46}$ Putting out in the medieval Flemish textile industry was considerably different from its eighteenth-century version in which male elite entrepreneurs provided raw materials and tools to rural workers. In medieval Flemish cloth production, the modes of putting out and small commodity production were not distinct, but rather intertwined in subcontracting networks of artisans in small workshops. ${ }^{47}$

In medieval Flemish 'putting out', the owner of the wool/cloth hired specialists (combers, spinners, etc.) to perform tasks in their homes or shops, provided them with materials and paid them for their work. ${ }^{48}$ This entrepreneur, called in the sources the 'draper' or the 'maker' of the cloth, managed the production of individual cloths separately, while early modern entrepreneurs aimed at bulk production in an economy of scale. Because each guild or occupation specialized in one stage of production, the cloth owner/entrepreneur put out work to both lowerlevel and higher-level producers. Many higher-level producers did not own the cloth they helped to make. Even if the guildsman, such a weaver, did own the cloth himself, he had to 'put out' all the other processes except the one performed by his own occupation. Labelling the organization of

(Lincoln, NB, and London, 1987), 123. As 5 pounds sterling was roughly equivalent to 2.4 pounds Flemish groten (average for the fourteenth century), six months' wages is a rough approximation. Spufford, Handbook, 200 and 215.

45 'Là seroit scelés, et devra li drapiers delivrer le seel entier au foullon, li foullon au licheur, et le licheur au tondeur, et le tondeur au caltre, sur telle amende que il plaira à nosseigneur', EP, \#704, no. 8, 1350-75, vol. III, 350.

${ }^{46}$ Holbach, 'Role of "putting-out"', 207-8; and idem, Frühformen von Verlag und Grossbetrieb in der gewerblichen Produktion (Stuttgart, 1994).

47 Farr, Artisans, 50-1.

${ }^{48}$ Holbach, 'Role of "putting-out"', 234; idem, Frühformen. 
lower-level production as 'putting out' and hiring of weavers, fullers or shearers as 'employment' or 'subcontracting' is in this sense misleading.

The dominant merchants, elite weavers and finishers could not have supervised the production alone, nor is there any evidence that they had large staffs of employees to manage subordinate workers. They did not hire factors to manage and supervise spinning by rural women, as the Florentine lanaiuoli (clothmakers) hired stamaiuoli (yarn dealers) in the following century. ${ }^{49}$

\section{Management by drapers}

Yet, the combination of specialization and decentralization required a complex organizational network. In addition to carrying the product from shop to shop (or house or yard) as it progressed through the manufacturing process, someone had to supervise and manage multiple specialized workers at the dispersed locations, contract for the work to be done, negotiate scheduling, delivery and wages or piece rates and ensure quality control. ${ }^{50}$ Someone had to advance the money or arrange the credit to buy the wool and pay the wages or piece rates of the workers, and wait for his or her reimbursement until the cloth was complete, which could take seven months. These managerial roles were filled by two middlingstatus occupations, drapers and small marketsellers, who organized and financed lower-level production of yarn and cloth.

The role of the first, drapers, is better known, as the relationship among merchants, guildsmen and drapers has been a topic of some interest to historians since Georges Espinas argued that large 'marchand-drapiers' organized extensive formalized putting-out systems as early capitalist entrepreneurs. ${ }^{51}$ Later, Hans van Werveke argued that 'merchantentrepreneurs' (koopman-ondernemers) were principally master weavers who acted as employers of others. These 'weaver-drapers' had a very thin profit margin, because most of the profits went to merchants. ${ }^{52}$ Later work clarified that these merchants and large drapers sometimes belonged to other guilds, and made most of their profits from buying wool and reselling it to lesser drapers and producers. ${ }^{53}$ Some small drapers purchased enough wool to make the cloth, retained ownership as the wool/cloth passed through the production process and received profits when they sold the cloth. Other drapers received financing from merchants

${ }^{49}$ R. De Roover, 'A Florentine firm of cloth manufacturers', Speculum, 16 (1941), 3-33, at 1314.

50 Munro, 'Symbiosis', 53; Holbach, 'Role of "putting-out"', 234-5; Endrei, 'Manufacturing', 14-23.

51 G. Espinas, Les Origines du capitalism, 4 vols. (Lille, 1933-49).

52 Van Werveke, Koopman-ondernemer; Van Houtte and Van Uytven, 'Nijverheid en handel', 99.

53 Boone, 'L'Industrie'; Holbach, 'Role of "putting-out"'. 
who commissioned production of cloth. ${ }^{54}$ Then drapers hired, scheduled, supervised and paid lower-level workers to prepare the wool. They gave out lots of wool to be carded, combed and spun, had it inspected and then woven into cloth.

An unusually detailed bit of evidence about the work of drapers comes from the property inventory of Wouter van Vinderhoute and his wife Aechte, a Ghent couple who died in 1360 . The property inventory survives on a chirograph, or piece of parchment, which listed Wouter and Aechte's belongings on one side and testimony about the debts they owed on the reverse. ${ }^{55}$ The inventory included one completed wool cloth (laken) appraised at 36 shillings groot, and material, valued at about 5 pounds groot, to make three wool cloths that were not yet finished. There were four lots of wool, weighing between 18 and 42 pounds, with individual values between 2 and 40 pence groot per stone. ${ }^{56}$ The multiple cloths and small lots of wool suggest that Wouter and Aechte were engaged in producing a number of cloths at different stages of the production process.

Wouter and Aechte worked together at draping. The evidence witnesses gave about the couple's debts shows that they used credit guaranteed by oral contracts to purchase materials and contract labour. The couple owed substantial sums to two dyers, and Aechte owed money to a warp-winder for four warps. Mergriete, the wife of Jacob van Lovendeghem, swore that Wouter and Aechte owed Jacob and her more than 3 pounds groot for one quarter of a sack of wool. Three men swore oaths that they had heard Aechte declare that 'she and her husband' (soe ende hare man) owed Jan de Beisere 42 shillings for butter (used to grease wool before combing) ${ }^{57}$

The Van Vinderhoute's inventory confirms the conclusion that merchants and elite guildsmen made much more profit than drapers. ${ }^{58}$ The couple owed, in total, more than 17 pounds groot, and their houses, business assets and possessions were worth just under 18 pounds groot. The inventory also supports the conclusion that drapers made cloths individually. Wouter and Aechte were managing the production of approximately six cloths at the time they died; one that was ready, three that were somewhere in the production process between weaving and

54 SAG, series 301, no. 1, fol. 219r, act no. 3, 9 Nov. 1360.

55 SAG, series 301, no. 1, loose chirograph numbered 215.1, dated 21 Aug. 1360.

56 'Item, 5-1/2 stones of wool, at 40 pence groot per stone [14.3 kilograms, 33 pounds, worth 18 shillings groot] Item, 7 stones of wool, at 2 p. gr. per stone [18.2 kilograms, 42 pounds, worth 1 shilling 2 pence groot] Item, 3 stones of wool, less one pound, blue, at 18 p. gr. per stone [7.4 kilograms, 17 pounds, worth 4 shillings 3 pence groot] Item, 3 stones and one pound of wool, at 8 p. gr. per stone [8.2 kilograms, 19 pounds, worth 1 shilling 5 pence groot].' In fourteenth-century Flanders, the stone (steen) was usually equivalent to 6 modern pounds. SAG 301, no. 1, chirograph 215.1.

57 'Mergriete Jacop wijf van Lovendeghem haudt bi haren ede dat Wouter van Vinderhaute ende siin wijf Jacob haren man ende hare sculdech siin van van [sic] I vierendele van I zacke wullen III lb. III s. VI d. gr', SAG 301, no. 1, chirograph 215.1.

58 Van Houtte and Van Uytven, 'Nijverheid en Handel', 99; D. Nicholas, Medieval Flanders (London and New York, 1992), 274-6; Boone, Gent, 60, 98; Stabel, 'Women at the market', 260-2. 
shearing and between two and four future cloths to be made out of the four lots of wool they had purchased. An Arras regulation suggested a similar number of cloths for drapers to have in process, as it required any draper working on more than six cloths at a time to finish those as soon as possible. $^{59}$

The Van Vinderhoute inventory and the keure regulations also suggest that drapers were a more diverse group than Van Werveke argued. Wouter may not have been a weaver. The clerk did not record his occupation, and the inventory did not contain a loom or other guild-specific equipment. Regulations from Arras and Ordenborch suggest that drapers hired weavers, as a weaver who made a mistake had to pay damages to the draper who had hired him to weave the cloth. ${ }^{60}$ Entries from the Bruges moneychanger Collard de Marke's account book list payments he made on behalf of a draper client for individual cloths purchased from 'weavers'. Between 1366 and 1370, the account book identified the 440 weavers, or small drapers, as 184 men, 222 women and 22 husbandand-wife partnerships. ${ }^{61}$ Women worked as drapers individually and as partners of their husbands, just as both Aechte and Wouter contracted legally binding debts related to their drapery business. ${ }^{62}$ Even when an Ypres ordinance identified drapers only with the masculine term, one provision complicates the gendering: 'If it happens that two come together in marriage of which one (li uns) is a draper and the other [has] another occupation, each can perform his occupation. ${ }^{63}$ These masculine pronouns appear to be masking the work of women as drapers. The mother of Marie Routaert, whose story opens this article, may have a draper while her husband worked at another occupation. Indeed, having two people to manage, negotiate, deliver and inspect the production of so many workers would be a real advantage.

Many regulations envisioned that some drapers were women. The Bruges keure of 1282 specified that both male and female citizens (die portre jof die portighe) could be responsible for making yarn from highquality wool and swearing oaths about the quality of the wool. ${ }^{64}$ Only in Saint-Omer, Linselles and Termonde did the clerks identify drapers

59 EP, Arras, 1344, \#100, no. 2, vol. I, 233.

60 EP Arras, fourteenth century, \#97, no. 13, vol. I, 125; Ordenborch, no date, \#622, no. 56, vol. III, 74.

61 J.M. Murray, Bruges: Cradle of Capitalism 1280-1390 (Cambridge, 2005), 308. Many thanks to Dr Murray for bringing this evidence to my attention and indicating that he identified the 440 entries as individual cloths by the amount paid out by De Marke.

62 Hutton, Women, 1-15, 35-58 and 103-22.

63 'Et s'il avenist que doi venissent ensamble par mariage don't li uns fust drappiers et li autres d'autre mestier, ke chascuns puisse faire sen mestier', EP, Ypres, 1280, \#750, no. 6, vol. I, 454.

64 EP, Bruges, 1282, \#139, vol. I, 369-70. See also Oudenbourg, \#622, nos. 36 and 40, vol. III, 74. In sixteenth-century Leiden, perhaps as many as 30 per cent of drapers were women. Howell, Women, Production, 70-7. 
exclusively in the masculine form. ${ }^{65}$ While weavers and shearers may have dominated draping by the fourteenth century, there was still room for other individuals, either male or female, to 'make cloth'.

In some cities, such as Arras, Bruges and Ypres, drapers held high status. ${ }^{66}$ When drapers were shown in positions of authority, the clerks always referred to them as men. A 1344 Arras ordinance dealing with sales to Portuguese merchants used the masculine 'drappiers' alone to identify those who dealt with the merchants, addressed the city magistrates, requested the ordinance and inspected the cloth, and the gender dyad 'drappiers et drappières' to identify those who made cloth, brought cloth to the inspectors and had it dyed. ${ }^{67}$ Gender designations thus point out the distinction between elite drapers (male) and ordinary drapers (male and female). As Howell showed for Douai, there was a division between 'large drapers', patricians who structured the entire city's drapery, and 'small drapers', managers of individual cloth production, who lacked political power and made modest profits. ${ }^{68}$ In other cities, such as Ghent, drapers were not listed among the powerful, but all drapers had at least middling labour status because they controlled the labour of others. ${ }^{69}$

Why did the merchants, master weavers and shearers, who reserved their leadership positions and guild masterships for men, tolerate the proliferation of female drapers? The most obvious answer is that female drapers were useful to them. Co-ordinating the production of the 10 to 20 lower-level workers in dispersed locations was time-consuming, and the profit from that co-ordination was likely minimal. The fact that many of those workers were female and their occupations were closely associated with women's household labour may have made it logical to let women organize the labour of other women. As Martha Howell noted, women drapers in Douai and female guildmembers in Cologne were often members of households and families that held high-status positions in related industries. ${ }^{70}$ Letting family women manage lower-level production of yarn could clearly benefit a male weaver, shearer or merchant.

Another answer concerns the financing of cloth production. Medieval Flemish women owned and controlled significant wealth because of the inheritance customary law. Sons and daughters inherited equal amounts

65 EP, Saint-Omer, 1250-1325, \#651, vol. III, 234-71; Linselles, 1395, \#611, vol. III, 40-4; Termonde, \#731-4, vol. III, 386-93.

66 EP, Bruges, 1282, \#138, vol. I, 362-8; contrast EP, Bruges, 1284, \#141, no. 1, vol. I, 398, in which 'drapeniers' are named as advisers of the count and aldermen in the keure, with \#141bis, no. D, 1289, vol. I, 445, in which the clerk used a gender dyad 'gheen drapenier jof drapeniere' to identify ordinary drapers who were forbidden to pay inflated wages to a fuller or shearer.

67 EP, Arras, 1344, \#100, vol. I, 232-4; see also 1315, \#79, vol. I, 200-2; 1347, \#91, vol. I, $214-15$. For Ypres, see 1280, \#750, vol. III, 453-4.

68 Howell, Women, Production, 61.

69 EP, Ghent, 1338, \#429-32, vol. II, 427-32. See also M. Boone, 'Nieuwse teksten over de Gentse draperie: wolaanvoer, productiewijze en coontrolepraktijken (ca. 1456-1468)', Bulletin de la commission royale d'historie, 154 (1988), 1-61.

70 Howell, Women, Production, 41-58. 
of their parents' property. ${ }^{71}$ Single women controlled inherited property without any restrictions. Between 13 and 20 per cent of these women remained single for at least a significant portion of their adult lives, and many never married. ${ }^{72}$ Widows typically received half of the couple's community property, which included profits that the husband and household had made. ${ }^{73}$ Many Flemish women would have had enough money, or enough property to secure credit, to buy wool and finance making a cloth. Mobilizing these women's wealth to finance production was in the economic interests of the drapery elites.

This gender analysis is significant because use of a gender dyad identifies a middling-status occupation. The use of male forms of an occupational title juxtaposed with gender dyad forms makes clear the distinction between the highest, privileged stratum reserved for a wealthy, dominant, elite, male group of masters, guild deacons and inspectors and the middle stratum of ordinary drapers. As long as that distinction was in place, the activities of women and non-elite men as small, ordinary drapers on the middle level did not threaten those men on the high level. In fact, their efforts were useful, because drapers funnelled adequate amounts of yarn and raw cloth, processed according to the quality control standards of the keure, to the guildsmen who finished the cloths and the merchants who sold them. Their work was not highly prestigious or very profitable, but it was essential to the drapery industry.

The middle level really compresses what was likely many descending levels of draping, from individuals managing the production of many cloths to those who managed production of part of the thread for a single cloth. At the lower end, there was not a huge social and economic difference between a small draper and a spinner, for example. If a spinner had enough money or owned property to secure credit enough to buy a small quantity of wool, she could put it out to three or four other spinners to earn extra profit for herself. If a spinner came into an inheritance, she might invest it in part of a sack of wool (such as the one quarter sack that Aechte and Wouter purchased from Mergriete and Jacob van Lovendeghem or the wool confiscated from Marie Routaert). These small efforts were not as efficient as an economy of scale, but the institutions of the corporations, the interests of small commodity producers and the logic of constant returns to scale prevented vertical integration. ${ }^{74}$ The

${ }^{71}$ Except in the case of fiefs, which followed primogeniture. P. Godding, Le Droit privé dans les Pays-Bas méridionaux du 12e au 18e siècle (Brussels, 1987), 350-4.

72 Hutton, Women, 31-2; J.M. Bennett and A.M. Froide (eds.), Singlewomen in the European Past, 1250-1800 (Philadelphia, 1999).

${ }^{73}$ Godding, Droit privé, 77-9 and 266-91; M. Boone, T. De Hemptinne, and W. Prevenier, 'Gender and early emancipation in the Low Countries in the late Middle Ages and early modern period', in J. Munns and P. Richards (eds.), Gender, Power and Privilege in Early Modern Europe (Harlow and London, 2003), 21-39, at 24-5.

${ }^{74}$ Farr, Artisans, 50. 
same institutions also opened up opportunities for many more small entrepreneurs to profit modestly.

\section{Management by marketsellers}

Putting out by drapers was not the only organizational model for cloth production. Keure regulations indicate that wool, thread and cloth were bought and sold at all stages of the production process. The ability to buy and sell component parts at the market meant that producers were not entirely dependent on work put out to them. The existence of small markets offered opportunities for another kind of entrepreneur, one who purchased from small producers, and resold their products for a modest profit.

Because wool arrived in 364 pound sacks (enough to make four large cloths), there was a need for small 'retail' dealers to sell (and thus distribute) lots of wool for producing one cloth at a time. ${ }^{75}$ Sacks contained whole fleeces, while different types of wool (from different parts of the fleece) were suited for warp and weft thread, and for different varieties and qualities of cloth. ${ }^{76}$ As a result, the contents of one imported wool sack ended up in multiple cloths. Since large merchants imported many sacks at a time, the volume of wool they exchanged was much larger than the small amounts drapers needed to make one cloth at a time. While there are no records of how many wool sacks went to each drapery town, English wool exports for 1356-60 totalled 32,666 sacks. If only 10 per cent of that ended up in Ghent, large merchants would have handled 3,270 sacks, valued at 27,435 Flemish pounds groot. ${ }^{77}$ The largest lot of wool in the Van Vinderhoute inventory was worth less than 2 pounds groot, and the smallest was valued at 6 pence, far below the interest level of a large merchant. Small merchants were needed to break down huge sacks of wool into small quantities to be sold at retail level to drapers and other producers.

While almost all large, international merchants were men, women were often small marketsellers for wool, cloth and yarn. ${ }^{78}$ In a pattern similar to the gendered division of drapers, keures identified virtually all large wool and cloth merchants and brokers by masculine occupational titles but used gender dyads for wool and cloth buyers and sellers. In Béthune, the clerks used the masculine form for brokers (ly courethiers) and gender dyads for those who sold wool, yarn and cloth (nus ne nulle). ${ }^{79}$ In Lille, retailers and hosemakers (detaillieres, detailleresse, cauceteres ne cauceteresse) sold

\footnotetext{
75 Endrei, 'Manufacturing', 16; Munro, Statistical Tables, Table 1, p. 3.

76 De Poerck, Draperie, 30-43.

77 Munro, Statistical Tables, Table 14, p. 35, using the 1360 mean price for all wools, 4.05 English pounds sterling, converted to 8.39 Flemish pounds groot.

78 Stabel, 'Women at the market', 261.

79 EP, Béthune, fourteenth century, \#128, vol. I, 315; also \#133, vol. I, 330-3.
} 
whole cloths and pieces. ${ }^{80}$ The gendered division indicates the distinction between the high-status merchants and smaller marketsellers with middle and low status.

The gendered division is confirmed by a 1338 Ghent ordinance reading that the brokers 'consented that the women (de vrouwen) could sell...fifteen stones of wool and not above that' ${ }^{81}$ Otherwise, women could not be involved in deals (ende els negheene vrouwe). ${ }^{82}$ Despite the restrictive intent, 15 stones of wool (equal to 39 kilos or 90 pounds) was enough to make half of a full cloth and to provide seven spinners with a week's employment. This amount is larger than any of the four individual wool lots in the Van Vinderhoute inventory. The women in the Ghent Cloth Hall were selling the smaller quantities of wool required to make individual cloths to drapers. As I have argued elsewhere, the male brokers handled the large deals; the 'women' handled retail sales, or sales of materials to the actual producers of cloth. ${ }^{83}$ The higher, more profitable level is distinguished by its restriction to men, while the presence of women identifies the usually hidden, lower, less profitable, retail level of sales that was absolutely essential to provide drapers with wool.

Women and husband-and-wife partnerships sold wool both in the main cloth halls and other halls and marketplaces. In a debt acknowledgement recorded in the Ghent aldermen's registers in 1360, Kateline van den Wale, a fuller's widow, swore that she owed Alise Monds and Simon den Vaudere almost 5 pounds groot 'for a good business deal for wool' that she and her late husband had purchased. ${ }^{84}$ The wife of Ghent wool merchant and alderman Ghiselbrecht van Coudenhove sold wool on credit in $1353 .{ }^{85}$ In Arras, sellers of combed wool for making worsteds (houppier/houppière) sold from stalls in the main cloth hall. ${ }^{86}$ The ordinance announced that women sold combed wool 'for the common profit of the drapery' (femmes qui vendoient le laine pinié, pour le commun prouffit de le drapperie). ${ }^{87}$

${ }^{80}$ EP, Lille, 1384, \#608, vol. III, 25-6. See also Ypres, late thirteenth century, \#763, no. 24, vol. III, 490, and Audenarde, \#151, no. 1, vol. I, 553.

${ }^{81}$ EP, Ghent, 1338, \#432, no. 5, vol. II, 431. For more on the role of brokers, see P. Stabel, 'Marketing cloth in the Low Countries: manufacturers, brokers and merchants (14th-16th centuries)' , in P. Stabel, B. Blondé and A. Greve (eds.), International Trade in the Low Countries (14th-16th Centuries): Merchants, Organisation, Infrastructure: Proceedings of the International Conference Ghent-Antwerp, 12th-13th January 1997 (Leuven and Apeldoorn, 2000) 15-36, at 19-25.

${ }^{82} \mathrm{~S}$. Hutton, 'Women, men, and markets: the gendering of market space in late medieval Ghent', in A. Classen (ed.), Urban Space: The Experience of Urban Life in the Middle Ages and 83 Ibid. the Early Modern Age (Berlin, 2009), 409-31.

${ }^{84}$ SAG, series 301, no. 1, fol. 225v, act no. 2, 19 Dec. 1360.

85 SAG, series 301, no. 1 , fol. $117 \mathrm{v}$, act no. 1 .

86 EP, \#77, nos. 27 and 28, vol. I, 198. See also \#101, no. 18, vol. I, 237; 1329, \#55, vol. I, 135; $\# 142$, vol. I, 453-7.

${ }^{87} \mathrm{EP}$, \#77, no. 11, vol. I, 196. 
There were specific 'yarn markets' in Ghent, Bruges, Ardenbourg, Arras and Saint-Omer. ${ }^{88}$ A 1282 Bruges ordinance directed those who wanted to buy or sell yarn to a specified area by St Salvator's churchyard. ${ }^{89}$ In 1284 , the aldermen ordered that wool sellers could not lay their wool down inside the church or take payment for wool inside the building..$^{90}$ In Ghent, there were three spaces for the sale of wool and thread - the Yarn House (garenhuus), the Wool House (twullehuus) and the Cloth Hall (ter pleinre hallen). ${ }^{91}$

Evidence of yarn sales and sizeable yarn marketplaces is particularly important, since their existence meant that combers, carders, spinners and other preparatory producers did not have to rely on putting out exclusively. Yarn merchants provided an alternate pathway for component parts to move from producer to producer - through sales of one worker's production on the open market. Spinners, living either in the city or in the villages nearby, could purchase small quantities of wool, process it into yarn and sell it for a profit at the Yarn Market. A spinner with enough cash or credit to buy a larger quantity of wool could provide wool to a few other women to work, and then sell their collective yarn production for a modest commission. Women and men with small amounts of capital might have invested in wool, paid others to process it and then sold the yarn for a profit. The existence of these markets enabled more people to invest in cloth products and make modest profits. By making small quantities of wool and yarn available at all stages of processing, small merchants or marketsellers performed another essential function in the decentralized, specialized production system.

\section{Conclusion}

To conclude, while we will never know the exact reasons why Marie Routaert's mother purchased or acquired a large sack of English wool and later left it to her daughter, there are a number of logical possibilities. The older Routaert may have been a draper or a small wool merchant, and her daughter was continuing her occupation. Marie may have broken up the sack of wool into lots and was selling the lots to drapers when the bailiff confiscated her goods. Marie may have been putting out the wool to carders, combers or spinners. Marie's petition and other bits of evidence surviving from the thirteenth and fourteenth centuries reconstruct a lost model of specialized craft production, a network of women and men

88 EP, Saint-Omer, \#651, no. 16, c. 1250-1325, vol. III, 235; Ardenbourg, fourteenth century, \#20, no. 47, vol. I, 52 .

$89 \mathrm{EP}, \# 139$, no. 6,1282 , vol. I, 370.

$90 \mathrm{EP}, \# 141$, no. 28, vol. I, 400 .

${ }^{91} \mathrm{EP}$, \#431, vol. II, 429-30. 
who bought, sold and worked wool and yarn to prepare it for weaving, with their own money, with others' money, working on credit or for cash.

Putting out in the pre-fifteenth-century Flemish drapery was quite different from the hierarchical putting-out system of early modern entrepreneurs. In medieval Flanders, many low-level producers lived and worked in the cities or smaller drapery centres, and networks of women (and men) centred in the towns and extending into the surrounding countryside organized the production stages before finishing. Gender dyads in the keures show that these organizers were women as well as men; more people had access to entrepreneurship in the medieval Flemish system. Drapers put out work not only to carders, combers and spinners, but also to weavers, fullers and dyers. The middle-level draper provided small amounts of capital and significant co-ordination skills, as he or she guided the process of cloth manufacture. In addition, the existence of yarn markets calls into question the dominance of putting out as the only method of organizing the lower levels of production.

This diffuse form of small commodity production through putting out/subcontracting managed by drapers and small marketsellers suited the institutional framework of the Flemish drapery towns. ${ }^{92}$ Despite their low pay, low status and lack of guild organization, lower-level producers, most of them women, performed more than half of the labour that went into making this cloth. Neither the elite merchants nor the guild structure would have been able to operate smoothly without drapers and small marketsellers to organize, finance and supervise the process.

Even though it did not prove permanent, the importance of the organizational model of the early wool cloth industry in Flanders to economic and gender studies goes beyond an esoteric local example of medieval urban crafts. Cloth-making was one of the earliest industries to move beyond production for the household and local consumption to production for distant markets. The organization of labour in the European site where this key industry first scaled up production for the international market cannot be dismissed as a marginal example.

Medieval Flemish wool cloth production was dominated by a small group of very wealthy men who did all they could to maximize their profits. And the lowest level of wool cloth production was dominated by women who worked for small recompense at preparing wool and spinning yarn. There was, however, a sizeable middling level of production, profit and authority, where some women could prosper. The fluidity of barriers between low-level occupations, such as spinning, and middlelevel occupations, such as draping, allowed women to purchase wool, hire other women to comb, card and spin it; or do some of that work

92 Farr, Artisans, 50-1; Van Bavel, Manors, 343-4. 
themselves, sell yarn they and others had produced and so earn a living. Looking at the small bits of surviving evidence about low-level wool cloth production through the lens of gender highlights the importance of the middle level of drapers and small merchants, upon whom both spinsters and merchants depended. 